\title{
Population structure and reproductive cycle of the commercial sea cucumber Holothuria mexicana (Echinodermata: Holothuroidea) in Belize
}

\author{
Arlenie Rogers ${ }^{1 *}$, Jean-François Hamel $^{2}$ \& Annie Mercier ${ }^{3}$ \\ 1. University of Belize Environmental Research Institute, P.O. Box 340, Belmopan City, Belize; arogers@ub.edu.bz \\ 2. Society for the Exploration and Valuing of the Environment (SEVE), St. Philips (Newfoundland), A1M 2B7, Canada; \\ jfhamel.seve@gmail.com \\ 3. Department of Ocean Sciences, Memorial University, St. John's (Newfoundland), A1C 5S7, Canada; \\ amercier@mun.ca \\ * Correspondence
}

Received 26-II-2018. C Corrected 21-VII-2018. Accepted 23-X-2018.

\begin{abstract}
The population and reproductive biology of the commercial sea cucumber Holothuria mexicana (Ludwig, 1875) was studied in Southern Belize (Caribbean Sea), including the sex ratio, size at sexual maturity and reproductive cycle, as well as the size structure among habitats located inside and outside protected areas. Individuals found inside marine protected areas were consistently larger than individuals found outside these boundaries. The male:female sex ratio was 1.1:1.0 with a unimodal size distribution composed mainly of sexually mature individuals $(87 \%)$. Size at sexual maturity was established to be $\sim 10 \mathrm{~cm}$ based on measures of gamogenetically mature individuals during the peak of the gametogenic maturity period. Juveniles and small adults measuring $\leq 15 \mathrm{~cm}(13 \%)$, were collected exclusively in sandy and muddy areas of seagrass habitats associated with mangroves. Larger adults were commonly found on hard substrates in both seagrass-associated and coral-reef-associated habitats. Based on histology and gonad indices, the first sign of early gametogenesis was detected in August in both sexes. Gametes developed and matured throughout the colder months between November and February. Decreases in gonad index in both years suggest annual spawning, starting in MarchApril 2014 (single major event) and March-April and July-August 2015 (two smaller events) for both males and females. The spawning periods were correlated with warmer or increasing temperatures, low rainfall and increasing or high chlorophyll- $a$ concentrations. These data will hopefully guide management and protection of the natural populations of $H$. mexicana, which are already suffering from overfishing in Belize and neighboring countries.
\end{abstract}

Key words: echinoderm; Holothuroidea; marine protected area; reproductive season; sexual maturity; size structure.

Rogers, A., Hamel, J.-F., \& Mercier, A. (2018). Population structure and reproductive cycle of the commercial sea cucumber Holothuria mexicana (Echinodermata: Holothuroidea) in Belize. Revista de Biología Tropical, 66(4), 1629-1648.

Spatial distribution and reproduction are closely interlinked in benthic marine invertebrates, including echinoderms (Mercier \& Hamel, 2009). Reproduction in sea cucumbers or holothuroids (Echinodermata: Holothuroidea) was demonstrated to require inter-individual chemical exchanges (Hamel \&
Mercier, 1996) and minimum densities of individuals to work efficiently (Anderson, Flemming, Watson, \& Lotze, 2011). Most known species of sea cucumbers reproduce sexually and are either gonochoric (Mercier \& Hamel, 2009; Leite-Castro et al., 2016) or in some cases hermaphroditic (e.g. Herrero-Pérezrul, 
Reyes-Bonilla, Garcia-Dominguez, \& CintraBuenrostro, 1999). Gametogenesis leading to gamete release typically follows seasonal and/ or monthly cycles in low latitudes (Mercier, Ycaza, \& Hamel, 2007; Leite-Castro et al., 2016), whereas it generally occurs annually, towards spring and early summer spawning in higher latitudes (e.g. Hamel, Himmelman, \& Dufresne, 1993). This is exemplified by the sea cucumber Isostichopus fuscus that reproduces seasonally between July and September in Mexico (Herrero-Pérezrul et al., 1999), but reproduces monthly year-round in equatorial latitudes along the coast of Ecuador (Mercier et al., 2007). Similar patterns were reported in the Indo-Pacific, e.g. in the sea cucumber Holothuria scabra (Conand, 1993a). The gonad index (GI) also exhibits seasonality in other tropical species such as H. atra (Chao, Chen, \& Alexander, 1994; Abdel-Razek, Abdel-Rahman, \& El-Shimy, 2005; Muthiga, 2006), Actinopyga mauritana (Hopper, Hunter, \& Richmond, 1998) and H. fuscogilva (Ramofafia, Battaglene, Bell, \& Byrne, 2000) and Stichopus herrmanni (Balogh, Wolfe, \& Byrne, 2018).

It is clear from the body of literature (e.g. Engstrom, 1980; Conand, 1982; Costelloe, 1985; McEuen, 1988; Hamel et al., 1993; Herrero-Perezrul et al., 1999; Drumm \& Loneragan, 2004; Muthiga, 2006; Mercier et al., 2007; Balogh et al., 2018) that mature oocytes and spermatozoa of broadcast-spawning species must be present at the same time in the water column and in sufficient concentration to insure adequate fertilization rates. A review of publications on the control of reproduction in sea cucumbers and other echinoderms indicates that several endogenous and exogenous factors, acting either successively or in synergy, may be implicated in reproductive coordination (Mercier \& Hamel, 2009). Exogenous factors controlling gametogenesis include temperature (Herrero-Perezrul et al., 1999; Drumm \& Loneragan, 2004; Toral-Granda \& Martínez, 2007), light intensity (Conand, 1982; Muthiga, 2006), photoperiod (Hamel et al., 1993), food availability (Smiley, McEuen, Chaffee, \& Krishan, 1991), and change in food type and diffusible chemical signals as well as chlorophyll- $a$ (Leite-Castro et al., 2016). Factors identified as spawning cues include light intensity (Cameron \& Fankboner, 1986; Hamel \& Mercier, 1995), time of the day (McEuen, 1988), seawater temperature (Conand, 1982), photoperiod (Conand, 1982), water velocity (Engstrom, 1980), salinity (Krishnaswamy \& Krishnan, 1967), a combination of seawater temperature and photoperiod (Costelloe, 1985), lunar phase (Mercier et al., 2007), as well as phytoplankton abundance (Hamel et al., 1993; Muthiga, 2006).

Of the 49 species of holothuroids reported for the Central American Caribbean Sea (Alvarado, Solis-Marin, \& Ahearn, 2008) at least 21 occur along the coast of Belize (Pawson, 1976; Hendler \& Pawson, 2000; Rogers, 2013), of which $H$. mexicana is the most abundant (Rogers, 2013). Both H. mexicana and its reported hybrid $H$. floridana $\times H$. mexicana (Fuente-Betancourt, Jesus-Navarrete, Sosa-Cordero, \& Herrero-Perezrul, 2001) are large species that can attain lengths of $\sim 50$ cm (Fuente-Betancourt et al., 2001; Hasbún \& Lawrence, 2002), although lengths of 58 and $76 \mathrm{~cm}$ for males and female, respectively, were reported from Florida, USA (Engstrom, 1980). The distribution range of $H$. mexicana is primarily in the Western Central Atlantic, in the Caribbean Sea (Bruckner, 2006), in Florida (Engstrom, 1980), Venezuela (Tagliafico, Rangel, \& Rago, 2011) and the Yucatan Peninsula (Mexico) (Fuente-Betancourt et al., 2001), although it has also been reported in the Azores (Toral-Granda et al., 2013).

Various aspects of population biology in $H$. mexicana, including density, abundance, distribution and size structure, have been studied in Mexico (Fuente-Betancourt et al., 2001), Panama (Guzman \& Guevara, 2002), Costa Rica (Bolaños, Bourg, Gomez, \& Alvarado, 2005), Venezuela (Tagliafico et al., 2011) and Belize (Rogers, 2013). Rogers (2013) documented high abundances of $H$. mexicana in Southern Belizean waters, with up to 12.9 ind $\mathrm{ha}^{-1}$. Based on habitat preferences, H. mexicana was found primarily in seagrass (Thalassia 
testudinum and Syringodium filiforme) (Hendler, Miller Pawson, \& Kier, 1995), coral rubble and patch reef habitats (Rogers, 2013). Fragmentary information is also available on the reproductive biology of $H$. mexicana. In Florida, gametogenesis and spawning were shown to occur during the spring-summer and late summer, respectively (Engstrom, 1980; Mosher, 1982). However, adults were noted to possess mature gametes from SeptemberNovember, outside peak spawning months (Engstrom, 1980). For the Curacao Reefs, van Veghel (1993) reported that $>70 \% \mathrm{H}$. mexicana individuals spawned after the full moon between August and October. In Panama, Guzman, Guevara, \& Hernandez (2003) set size at sexual maturity for $H$. mexicana between $13-15 \mathrm{~cm}$ and its maximum reproductive activity between May-July, when the temperature was $2{ }^{\circ} \mathrm{C}$ above the annual average and $3-4{ }^{\circ} \mathrm{C}$ higher than the lowest monthly average.

In espite of $H$. mexicana being the most abundant sea cucumber in the Caribbean as well as one of the most important commercial species in the region, basic biological questions remain incompletely answered and do not allow a full understanding of their vulnerability and resilience to growing anthropogenic pressures (loss of habitat, pollution and increased fishing pressure). Moreover, H. mexicana has been commercialized in Haiti (Ramdeen, Belhabib, Harper, \& Zeller, 2012; Masters, 2014; Global Companies, 2015), Martinique (Daniel Taverny, sea cucumber exporter, pers. comm., February 2017), Honduras (SAGARPA, 2015), Nicaragua (Rogers, Hamel, \& Mercier, 2017), Jamaica (Jamaica Observer, 2015; Kong, 2016), Mexico (Toral-Granda, 2008) and Belize (Perez \& Garcia, 2012). In an effort to provide information of value to decision makers regarding the sea cucumber fishery in Belize and elsewhere in the distribution range of $H$. mexicana, the objectives of this study were to: (1) determine its annual reproductive cycle and spawning periodicity; (2) establish correlations with environmental variables (e.g. rainfall, temperature); and (3) analyze the population structure inside and outside protected areas and among habitats.

\section{MATERIALS AND METHODS}

Collection of sea cucumbers for size structure analysis: A total of 2333 individuals of H. mexicana (Ludwig, 1875) were collected between February 2014 and September 2015 by snorkeling in the Caribbean Sea off Southern Belize (Fig. 1). The presence of other sea cucumber species was also documented. Each month, 32 to 400 individuals with lengths between 8 and $47 \mathrm{~cm}$ (measured mouth-anus in relaxed state underwater) were collected. The size structure (based on length and eviscerated wet weight) in fished and in protected areas was established from seagrass beds, coral rubble, sand and patch reefs around various cayes (small, low island on a coral reef platform) located either inside, adjacent to, or not near any of four marine protected areas (MPAs) (Fig. 1 and Supplementary material 1).

Size at sexual maturity, sex ratio and reproductive cycle: During the monthly collection (February 2014 to September 2015) $\sim 30$ adult individuals measuring $24.1 \pm 6.3 \mathrm{~cm}$ SD $(n=587)$ were used to calculate the gonad index (GI) as percent ratio of gonad weight to eviscerated wet weight, and to conduct histological analysis (Shiell \& Uthicke, 2006; Rasolofonirina, Vaitilingon, Eeckhaut, \& Jangoux, 2007; Toral-Granda \& Martínez, 2007). The gonad and all internal organs were extracted and excess water drained before taking the eviscerated weight. The body wall (including the muscle bands and aquapharyngeal bulb) was measured, and weighted wet (Chao, Chen, \& Alexander, 1995; Conand, 1981; Guzman et al., 2003; Leite-Castro et al., 2016). The sex for each individual was established visually from the color of the gonad; creamy or white for the males and orange for the females (Herrero-Perezrul et al., 1999; Guzman et al., 2003; Leite-Castro et al., 2016). A sample of 30 gonads per month were prepared histologically for sex confirmation and level of gonad 


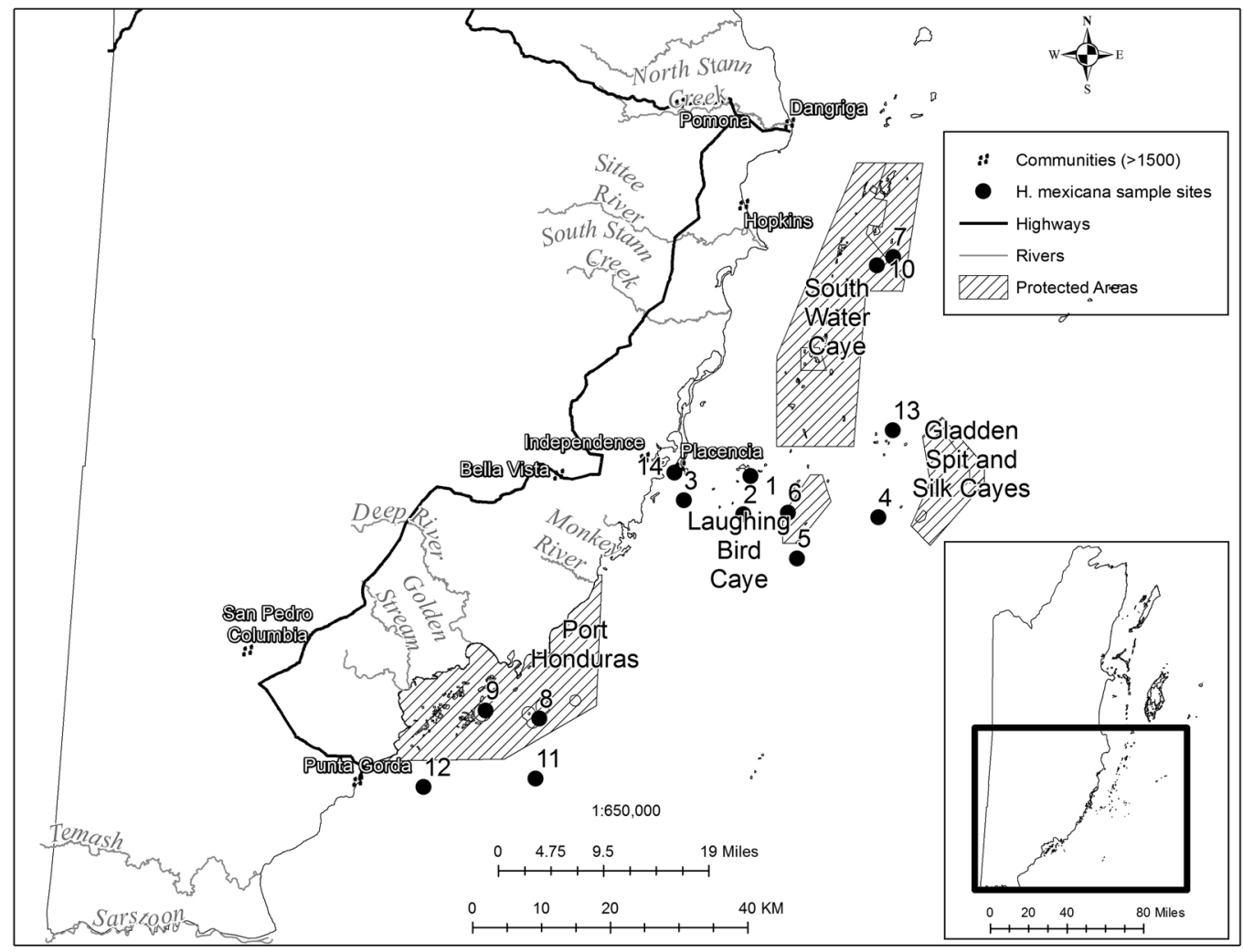

Fig. 1. Collection sites for H. Mexicana in Belize. 1. Lark Range (16 $30.339^{\prime}$ N: $088^{\circ} 16.337^{\prime}$ 'W), 2. Sypio (16 $27.307^{\prime}$ N: $088^{\circ} 16.913^{\prime}$ W), 3. East Placencia $\left(16^{\circ} 28.377^{\prime} \mathrm{N}\right.$ : $088^{\circ} 21.77^{\prime}$ W), 4. Little Water \& Hatchet $\left(16^{\circ} 27.135^{\prime}\right.$ N: $088^{\circ} 05.860^{\prime}$

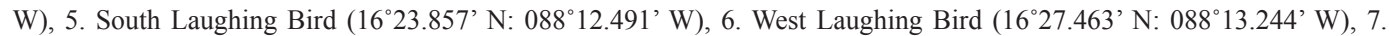
Pelican Range $\left(16^{\circ} 47.688^{\prime}\right.$ N: $088^{\circ} 04.7635^{\prime}$ W), 8. Snake Cayes $\left(16^{\circ} 11.092^{\prime}\right.$ N: $088^{\circ} 33.438^{\prime}$ W), 9. Tarpon and Abalone $\left(16^{\circ} 11.690^{\prime} \mathrm{N}\right.$ : $\left.088^{\circ} 37.828^{\prime} \mathrm{W}\right), 10$. Tobacco $\left(16^{\circ} 47.021^{\prime} \mathrm{N}\right.$ : $\left.088^{\circ} 06.097^{\prime} \mathrm{W}\right), 11$. Southeast PHMR $\left(16^{\circ} 06.347^{\prime} \mathrm{N}\right.$ :

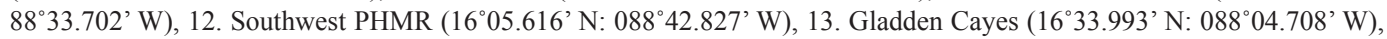
14. Placencia Lagoon ( $16^{\circ} 30.569^{\prime} \mathrm{N}$ : $\left.088^{\circ} 22.536^{\prime} \mathrm{W}\right)$.

maturity (described below). Each entire gonad was preserved in $70 \%$ ethanol, subsequently fixed in Bouin's solution for $24 \mathrm{~h}$, washed alternately in water and $50 \%$ ethanol several times, and finally preserved in $70 \%$ ethanol. The gonads were then dehydrated in a graded series of ethanol baths, embedded in paraffin and sectioned at $1 \mu \mathrm{m}$ for slide preparation. They were stained with Mayer's hematoxylin and eosin (Galigher \& Kozloff, 1971; Guzman et al., 2003). Five gonad developmental stages were identified for each individual based on Hamel et al. (1993): Stage I post-spawning, Stage II recovery, Stage III growth, Stage IV advanced growth and Stage $\mathrm{V}$ mature (see descriptions in the Results section). Sex ratio was established for the entire study but also inside each monthly sample. The size at sexual maturity was determined based on the smallest individuals in samples collected during full gonad maturity period (around March).

\section{Correlation with environmental factors:}

To understand the influence of external factors on the reproduction of $H$. mexicana in a location that is characterized by a dry and a rainy season (National Meteorological Service of Belize, 2017), monthly GI and gametogenic stages were compared with the following: mean monthly surface water temperature 
collected using a YSI Pro Plus Multi-parameter probe at each site; average monthly rainfall data obtained from the Meteorology Department for the Punta Gorda Town weather station (National Meteorological Service of Belize, 2016); mean monthly salinity obtained from the Toledo Institute for Development and Environment (Foley, Alvarez, Moore, Requena, \& Warns, 2015); chlorophyll- $a$ obtained from the National Aeronautics and Space Administration (NASA, 2015); day length obtained from Time and Date AS (2015); and tide level data obtained from Mobile Geographics (2016).

After confirming normality and homogeneity of variances using Kolmogorov-Smirnov and Levene's tests, respectively, analysis of variance (ANOVA) was carried out to compare sea cucumber lengths across sites and habitats. Post-hoc pairwise comparisons were conducted using Tukey's tests. A Mann-Whitney U test was used to compare the difference between male and female GI. The sex ratio was tested for equality using a Chi-square test. Pearson correlation was used to test the relationship between mean monthly GI and environmental factors for males and females separately. All analyses were conducted using Statistical Package for Social Sciences (SPSS; IBM, 2012).

\section{RESULTS}

Population structure: When all sites and dates were combined, the size distribution was unimodal and dominated by individuals of 20 cm (Fig. 2 and Fig. 3). Mean length was 22.4 $\pm 0.2 \mathrm{~cm}$ and ranged from 8 to $47 \mathrm{~cm}$. The mean lengths of individuals varied significantly among the various sites and habitats (ANOVA: $\mathrm{P}<0.001$ ), as detailed below.

In seagrass/coral rubble and sand, the largest individuals $(\mathrm{n}=9$; $46-47 \mathrm{~cm} ; 430-837 \mathrm{~g})$ found near Tobacco Caye at a depth of $11.3 \mathrm{~m}$ were significantly larger (Tukey SD, $\mathrm{P}<0.05$ ) than those found in all other habitats. The smallest individuals $(n=49)$ found in those habitats were between 10 and $13 \mathrm{~cm}$, had a mean eviscerated wet weight between 35 and $65 \mathrm{~g}$ and were found in Lark Range, Tobacco,
Gladden, Southeast PHRM, Southwest PHMR and Placencia Lagoon (Fig. 1; Supplementary material 1). In seagrass/sand habitats, the largest individuals $(\mathrm{n}=45 ; 40-41 \mathrm{~cm} ; 644-789$ g) were found at various depths (Supplementary material 1) at Southwest PHMR, Placencia Lagoon, Sypio Caye and Tarpon and Abalone. The smallest individuals $(\mathrm{n}=51 ; 10.5-12 \mathrm{~cm}$; 35-52 g) were found at Lark Range, Snake Cayes, Placencia Lagoon, Sypio, East Placencia, Southeast and Southwest PHMR (Fig. 1; Supplementary material 1). In seagrass/sand and mud habitats (in the Placencia Lagoon), the largest individuals $(\mathrm{n}=12 ; 35-39 \mathrm{~cm} ; 650-893$ g) were found at various depths (Supplementary material 1$)$ and the smallest $(\mathrm{n}=2 ; 8 \mathrm{~cm}$; 16-24 g) contained no gonad. Habitat for the latter was near mangroves (Rhizophora mangle) at depths of $1.2 \mathrm{~m}$ (Fig. 1; Supplementary material 1). In patch coral/sand and seagrass the largest individuals $(\mathrm{n}=12 ; 40-46 \mathrm{~cm} ; 90$ to $590 \mathrm{~g}$ ) were found at various depths in Lark Range, Southeast PHMR, Little Water and Hatchet and Tarpon and Abalone (Supplementary material 1; Fig. 1). The smallest individuals $(\mathrm{n}=21 ; 13-14 \mathrm{~cm} ; 72-117 \mathrm{~g})$ were found at Southwest PHMR, Little Water and Hatchet and Snake Cayes.

Eviscerated wet weight distribution was unimodal. The mean for all individuals collected ranged from 14 and $1088 \mathrm{~g}$ with a mean of $317 \pm 2.7 \mathrm{~g}$ (Fig. 3). The heaviest individuals $(\mathrm{n}=89)$ had a mean weight of $380 \mathrm{~g}$ (550-949 g) and a mean length of $38.5 \mathrm{~cm}(31-46 \mathrm{~cm})$; they were found in areas within or adjacent to MPAs, including Tobacco, Gladden, Little Water, Hatchet and Snake Cayes (Fig. 3). On average, there was a positive relationship between length and weight (Fig. 4) for all individuals, regardless of where they were collected relative to MPAs.

Other sea cucumber species: Several other species were present in the various sites; these included Isostichopus badionotus (along with $H$. mexicana in seagrass-associated habitats at all sites), H. thomasi (in coral patches East Placencia), Astichopus multifidus (in 


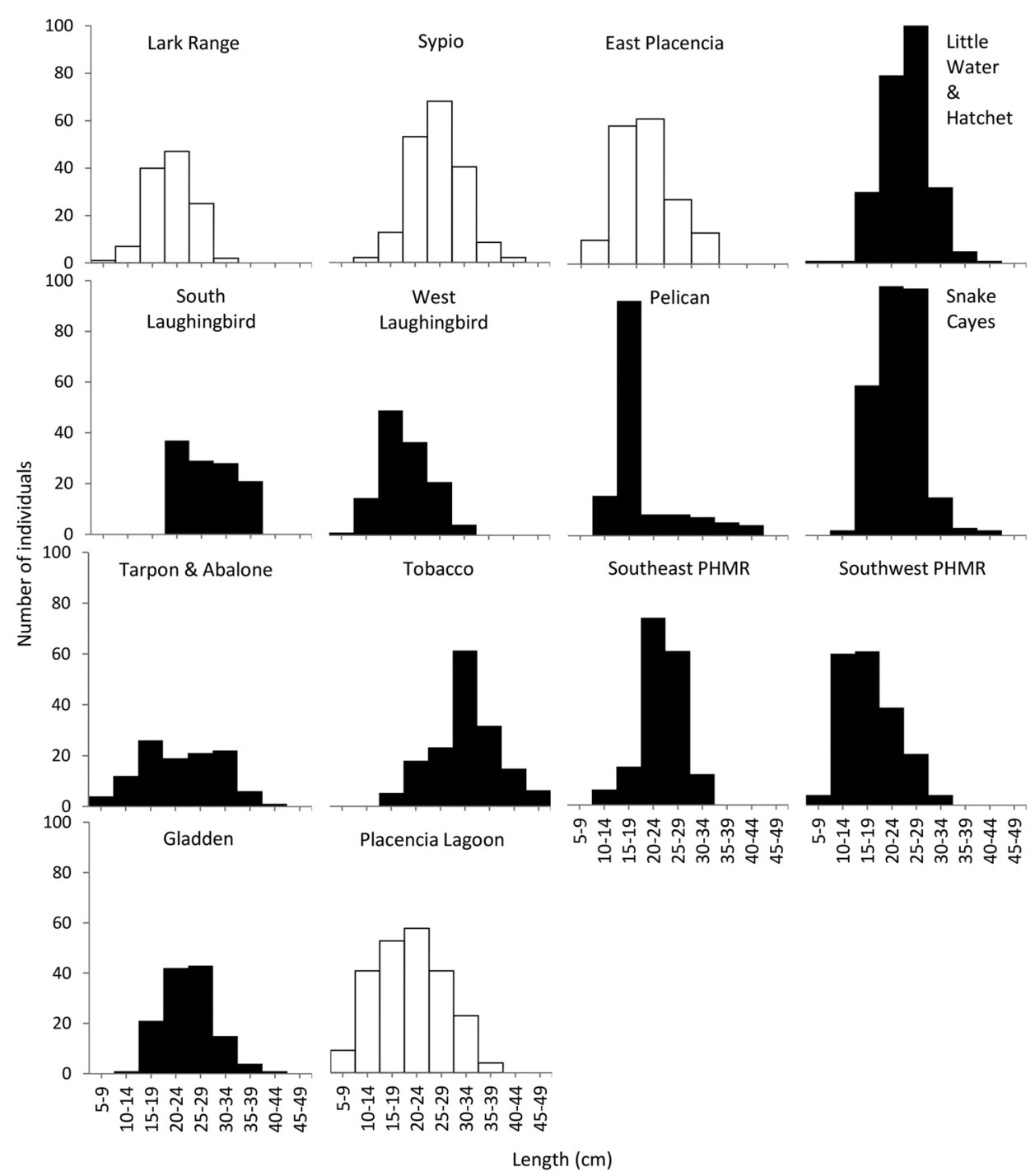

Fig. 2. Length distributions of H. mexicana found inside (black fill) and outside (white fill) boundaries of marine protected areas. See Supplementary material 1 for collection site geographic coordinates, depth and MPA proximity and Fig. 1 for map of collection sites.

coral-associated areas between SWCMR and GSSCMR), Actinopyga agassizi (along with $H$. mexicana in seagrass-associated areas at Tarpon and Abalone in the PHMR and East Placencia; see Fig. 1 and Supplementary material 1), Euapta lappa (only at night at Pelican Range in the SWCMR; see Fig. 1 and Supplementary material 1) and $H$. floridana (along with $H$. mexicana in seagrass-associated habitats at all sites; see Fig. 1 and Supplementary material 1), and three other currently unidentified species (in seagrass habitats East Placencia; see Fig. 1 and Supplementary material 1).

Sex ratio and size at sexual maturity: Overall, there were 27 adult-sized individuals that had no gonad, 2 hermaphrodites (Fig. 5M), 290 males and 268 females, yielding a male:female ratio of 1.1:1.0. The slight apparent dominance of males was not significant 


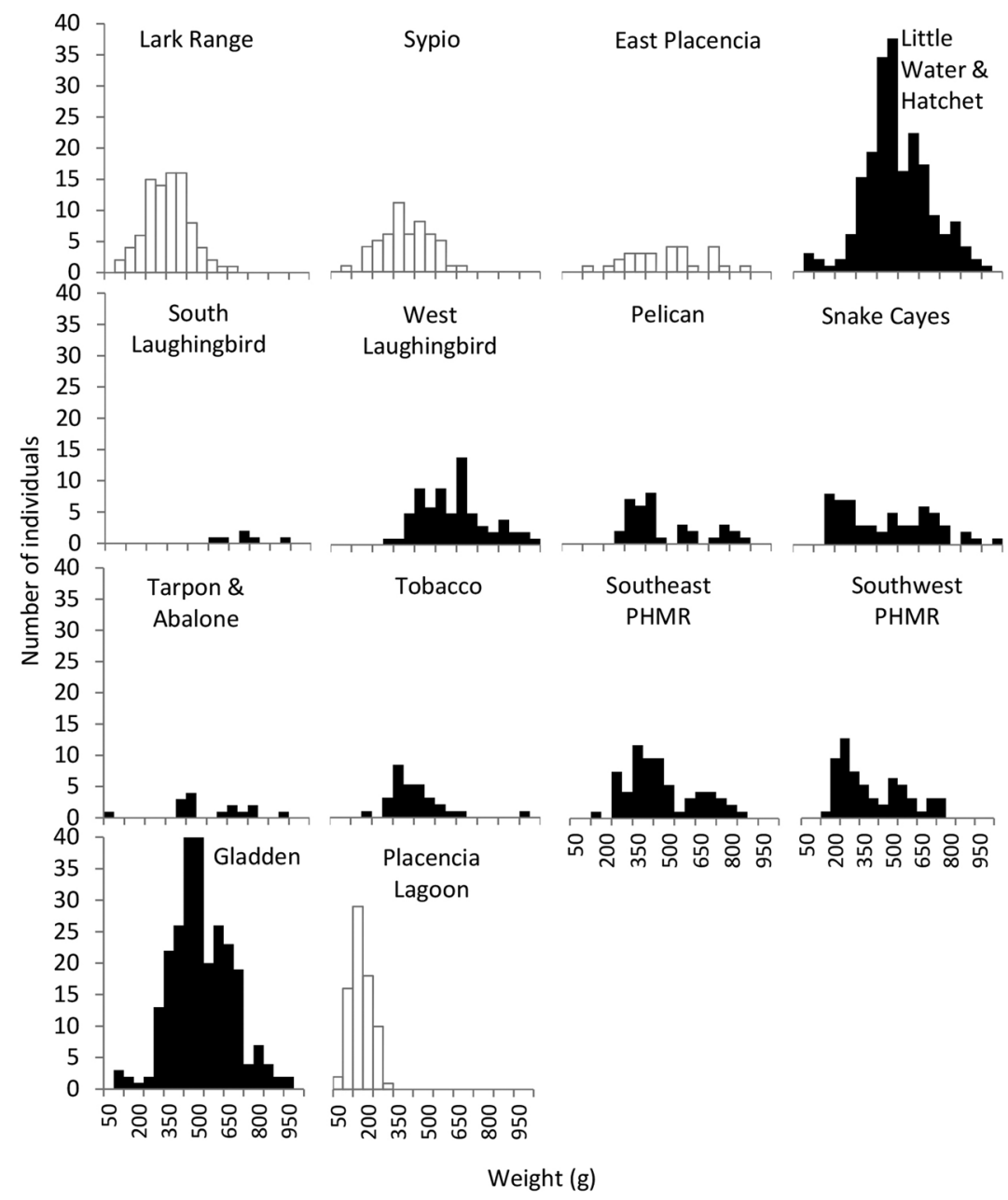

Fig. 3. Eviscerated wet weight distributions of H. mexicana found inside (black fill) and outside (white fill) boundaries of marine protected areas. See Supplementary material 1 for collection site geographic coordinates, depth and MPA proximity and Fig. 1 for map of collection sites.

(Chi square: $\mathrm{P}=0.310$ ). Moreover, monthly collections provided more males than females in some months and vice versa in other months (Supplementary material 2). The slight male dominance in two sites (Sypio and Tarpon) was not significant (Chi square: $\mathrm{P}=0.34$ and 0.38 , respectively). Thirteen of the 27 individuals without gonad were found in Placencia Lagoon and ranged from 8 to $23 \mathrm{~cm}$ in length; the other 14 individuals were found in areas near Gladden $(n=1)$, Lark Range $(n=6)$, East Placencia $(\mathrm{n}=1)$ and Snake Cayes $(\mathrm{n}=6)$, and ranged from $14-29 \mathrm{~cm}$.
The minimum size at sexual maturity was determined to be around $10 \mathrm{~cm}$ in length for both sexes; a size at which both mature and immature individuals occurred. However, it was only at $16 \mathrm{~cm}$ that $100 \%$ of individuals were found sexually mature. Macroscopic and microscopic examinations confirmed that cream or white gonads were testes and that orange or purple gonads were ovaries. Macroscopically, the gonad tubules composing the testes were ramified, thinner and on average smaller than the ovaries, which were unramified and heavier. Specifically, testes of all 


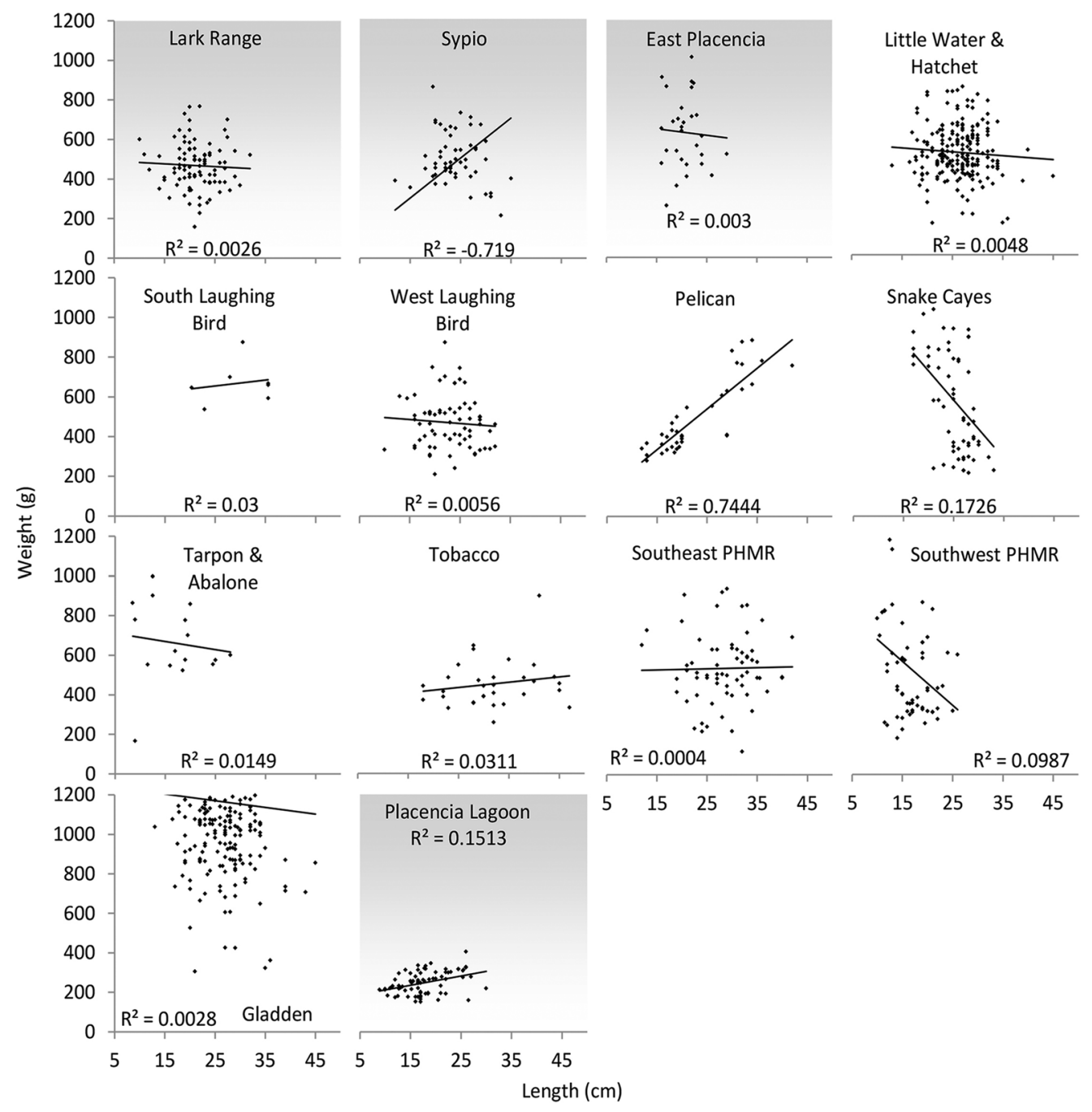

Fig. 4. Length and eviscerated wet weight relationship of H. mexicana found inside (no fill) and outside (gray fill) boundaries of marine protected areas. See Supplementary material 1 for collection site geographic coordinates, depth and MPA proximity and Fig. 1 for map of collection sites.

stages combined had a mean weight of $16 \pm 2 \mathrm{~g}$ ranging from 0.2-103 g, while ovaries of all stages had a mean weight of $26 \pm 2 \mathrm{~g}$, ranging from $0.5-305 \mathrm{~g}$, with a significant difference between the two (Mann-Whitney, $\mathrm{P}<0.001$ ).

Reproductive cycle: Histological analysis showed that the variations in gonad weight, color and tubule diameter reflected different gametogenic stages (level of maturity). Detailed descriptions of the stages are provided in Supplementary material 3. The oogenic and spermatogenic stages illustrated in Fig. 5, and Fig. 6 show the monthly proportion of each stage in the sampled individuals. In 2014, the proportion of post-spawning stage (I) in males was the highest in August (74\%) and it remained relatively high through December (49-65\%); it was also high in April-May (60-65 \%). In 2015, the highest proportions of post-spawning males were again April-May (58 \%), and August and September (69\% 


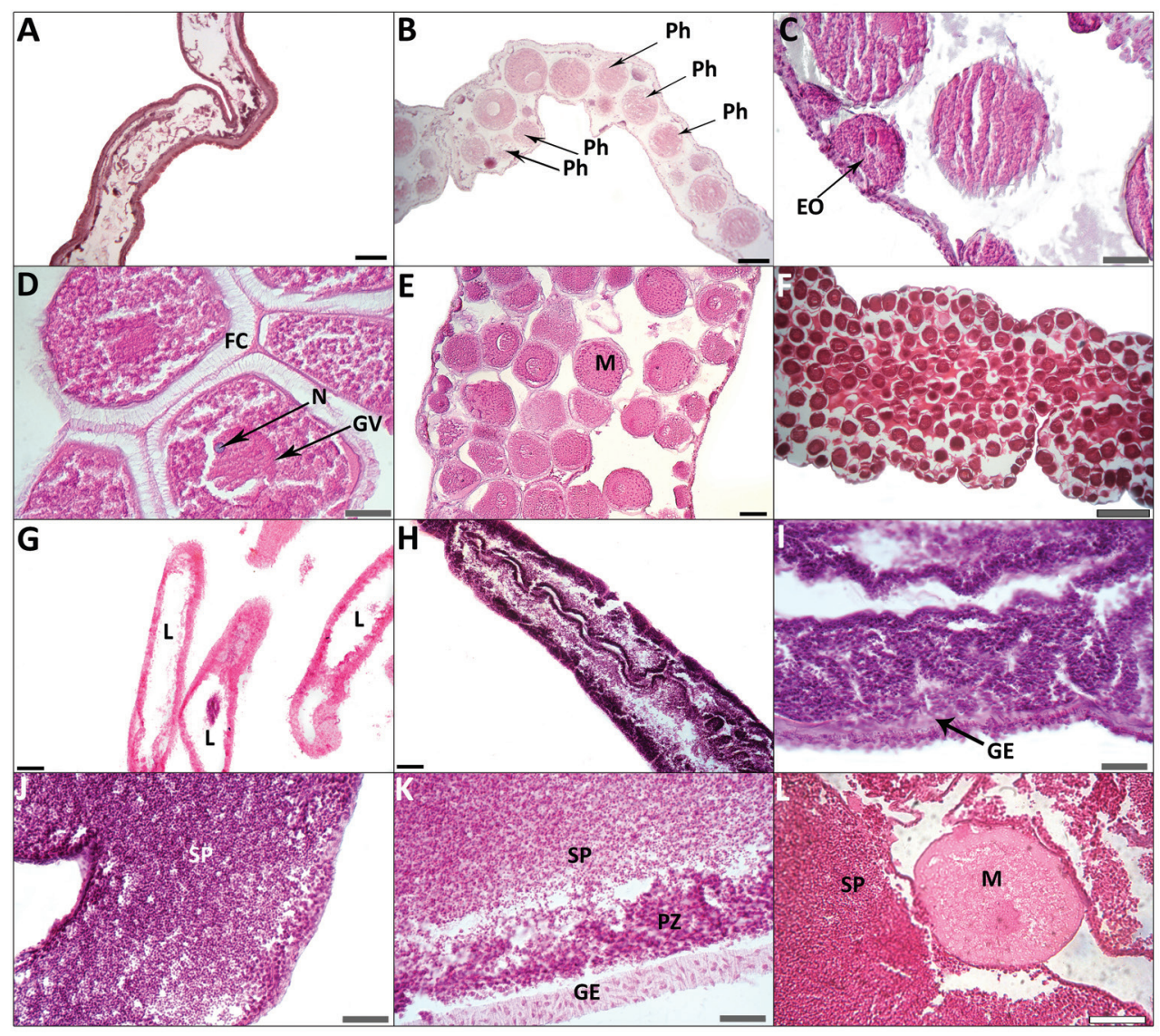

Fig. 5. Holothuria mexicana. Light micrographs of female tubules illustrating the oogenic cycle. (A) Post-spawning; (B) Recovery stage showing nutritive phagocytes $(\mathrm{Ph})$ inside residual oocytes; (C) Growth stage showing early oocytes (EO) in a rather empty lumen; (D) Advanced-growth stage showing abundance of mature oocytes with germinal vesicle (GV), nucleoli (N), follicular cells (FC) and Germinal Vessicle (GV) around nucleous; (E) and (F) Mature stage showing lumen filled with mature oocytes (M). Light micrographs of male gonad tubules illustrating the spermatogenic cycle. (G) Post-spawning testis showing empty lumen areas in the gonad tubules (L); (H) and (I) Growth stage showing the highly convoluted germinal epithelium (GE); $(\mathrm{J})$ and $(\mathrm{K})$ Mature stage showing the thin gonad tubule wall, reduced or absent proliferation zone (PZ), and great numbers of spermatozoa (SP) in the lumen; (L) Hermaphrodite showing a mature oocyte (M) surrounded by a large number of spermatozoa (SP). Black scale bar represents $100 \mu \mathrm{m}$ (A, B, E, G, H); grey scale bar represents $40 \mu \mathrm{m}(\mathrm{D}$, $\mathrm{F}, \mathrm{I}, \mathrm{J}, \mathrm{K})$ and white bar represents $500 \mu \mathrm{m}(\mathrm{C}, \mathrm{L})$.

and $79 \%$, respectively; Fig. 6A). Males in recovery stage (II) were more frequent from September to November 2014 (35-49\%), and reached 26\% in September 2015 (Fig. 6A). Male gonads in growth stage (III) occurred more frequently in February of 2014 (40 \%) and in January of 2015 (77\%; Fig. 6A); this stage was found in all months except in March, April and May of 2014, and March and May of 2015. The advanced-growth stage (IV) in males was more frequent in February (45\%) of both years, whereas the mature stage (V) dominated in March (88\%) and July (83\%) of 2014 and in the same months of 2015 (83\% and $92 \%$, respectively; Fig. 6A). In 2014, the proportion of post-spawning (I) females was the highest in April, May and August (30\%, $37 \%$ and $32 \%$ respectively) and in April, August and September $(60 \%, 69 \%$ and $47 \%$ respectively) (Fig. 6B). Female gonads in 


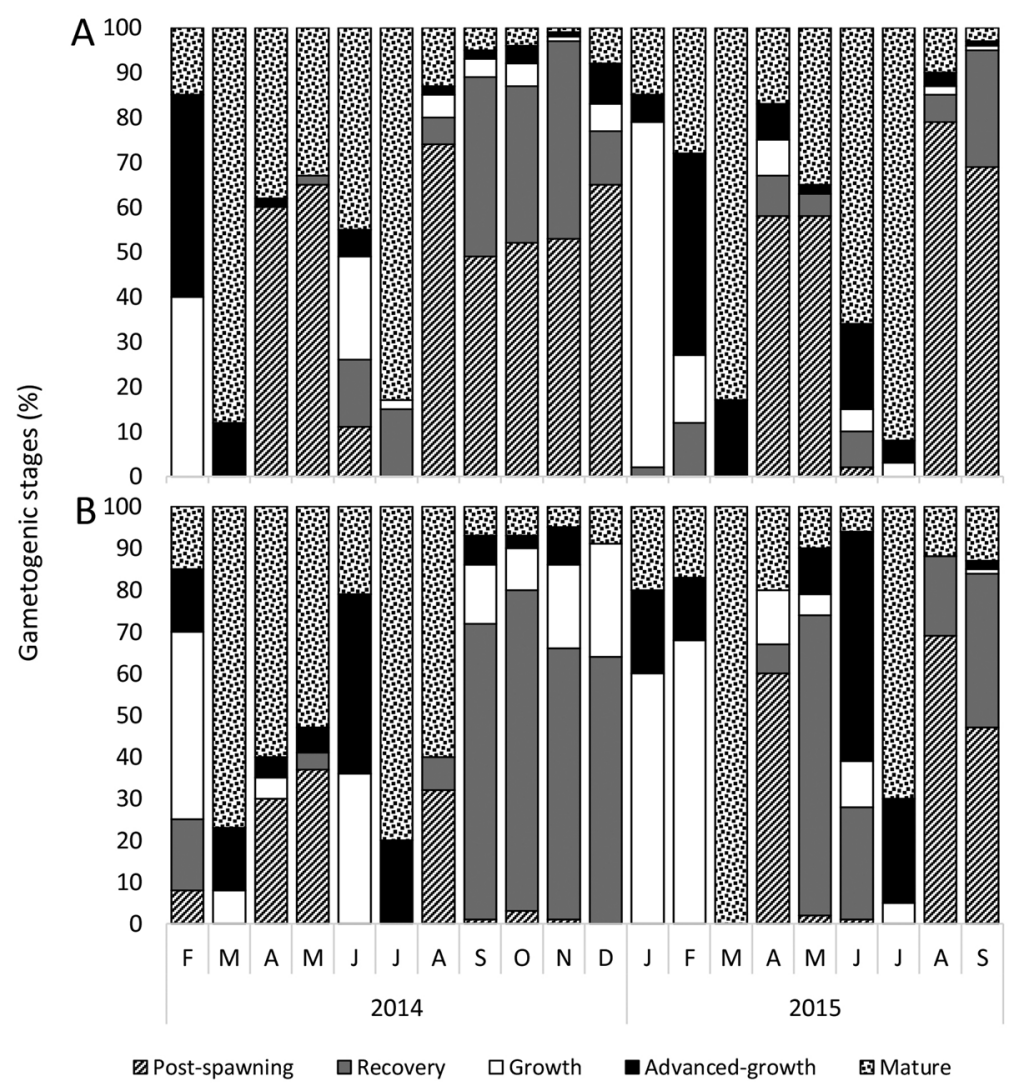

Fig. 6. Monthly percentage of each gametogenic stage for (A) males and (B) females from February 2014 to September 2015.

the recovery stage (II) generally dominated through the fall of 2014, representing $71 \%$ and $77 \%$ in September and October, respectively, whereas in 2015 it was more frequent in May (72\%) and only $38 \%$ in September (Fig. 6B). The highest proportion of female gonads in growth stage (III) was $45 \%$ in February and $36 \%$ in June of 2014 and it occurred more frequently in January-February of 2015 (60$68 \%$; Fig. 6B). The female advanced-growth stage (IV) dominated in June of both years (43 and $56 \%$, respectively). Based on the dominance of mature and advanced-growth stages, immediately followed by the appearance of post-spawning stages, seen in both sexes, the spawning months were identified as March and July of both years (Fig. 6).

Gonad indices (GI) in both sexes displayed similar seasonal patterns (Fig. 7G). A gradual increase in mean GI from January-February for both 2014 and 2015 was observed. GI peaks were detected in March of 2014 and 2015 and July 2015 for females. For males, GI peaks were detected in March 2014 and March and June 2015. A gradual decline in GI followed from April to September 2014 for both males and females. The lowest GI values of the annual cycle was from October to January 2014, in both males and females. Similarly, in 2015, there was a gradual decline in GI values for both males and females from April to May but they increased again in June and July and underwent a gradual decrease again in August and September.

Environmental Factors: During the annual cycle, the GI was positively correlated with sea surface temperature $(r=0.547$, 

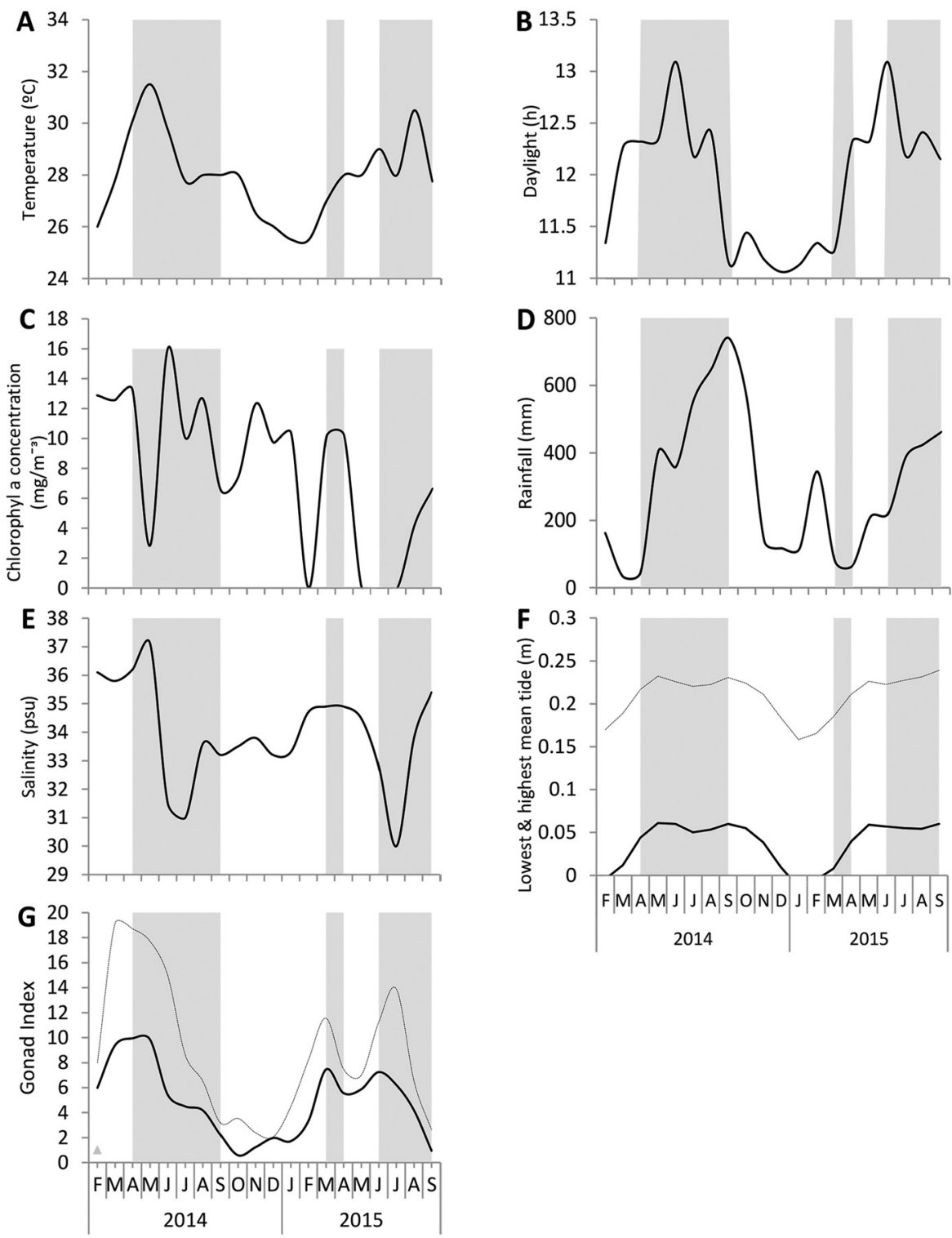

Fig. 7. Environmental parameters measured during the study of H. mexicana from February 2014 to September 2015. (A) sea surface temperature $\left({ }^{\circ} \mathrm{C}\right)$; (B) day length $(\mathrm{h})$; (C) chlorophyll- $a\left(\mathrm{mg} \mathrm{m}^{-3}\right)$; (D) rainfall $\left(\mathrm{mm} \mathrm{month}^{-1}\right)$; (E) salinity (psu); (F) lowest (continuous line) and highest average tide (dotted line); (G) mean monthly male (continuous line) and female (dotted line) GI. The gray highlights identify months of spawning periods in H. mexicana.

$\mathrm{P}<0.05$; Fig. 7A). The GI started to increase from February to March 2014 with warming temperatures and started to decrease as temperatures dropped from March-April to September. From September 2014 to January 2015, the GI remained at its lowest, concurrent with the coldest temperatures of the annual cycle, and started to increase again in JanuaryFebruary 2015 until March 2015. Correlations were also detected between GI and day length $(\mathrm{r}=0.552, \mathrm{P}<0.05$; Fig. 7B) with GI values increasing with day lengths and decreasing as 
days grew shorter. Spawning periods starting between March and April in 2014 and 2015 and again in July-August 2015 showed correlations with fluctuations and peaks in chlorophyll- $a$. There was a correlation between peak GI and an increase in chlorophyll- $a$ levels ( $\mathrm{r}=0.551$, $\mathrm{P}<0.05$; Fig. 7C) and the decrease in salinity $(r=0.671, P<0.05$; Fig. 7E). Similarly, there was a parallel between peak GI and the highest high tides (Fig. 7F).

\section{DISCUSSION}

Small individuals of Holothuria mexicana found in the present study (around $8 \mathrm{~cm}$ long) were much smaller than the smallest individuals found in Panama $(16 \mathrm{~cm})$ (Guzman et al., $2003)$ and in Mexico $(17 \mathrm{~cm})$ (Fuente-Betancourt et al., 2001). Although there is currently no regulation to limit the harvest size (Rogers, Hamel, Baker, \& Mercier, 2018), fishers typically caught individuals of $\sim 12-24 \mathrm{~cm}$ total length (Perez \& Garcia, 2012), which is above the length at first maturity found here. It is not clear how many are actually harvested annually since the Total Allowable Catch (TAC) is based on wet weight, and the exported volume (as partially or fully dehydrated sea cucumber cucumbers) is used to estimate whether the TAC has been met. Because the dry weight of a sea cucumber is about $5-25 \%$ of its wet weight, this method allows the capture to exceed the quota, which may explain the drastic decline in abundance of both targeted sea cucumber species along the coast of Belize, forcing the closure of the fisheries in 2017 (Rogers et al., 2018). Their small size and abundance in the Placencia Lagoon in Belize (not seen elsewhere throughout the study sites) may suggest that a nursery habitat could be located near or within this site. The area was characterized by shallow seagrass, coral rubble, mud and sand habitats, which were all in the vicinity of Red mangrove forests (Rhizophora mangle). This finding is consistent with studies identifying seagrass close to mangroves as nursery areas for another tropical Holothuroidea sea cucumber, H. scabra, in the Solomon Islands
(Mercier, Battaglene \& Hamel 2000). The Placencia Lagoon, which is far from any MPA is challenging the assumption that the presence of MPAs can promote or enhance recruitment at least in the areas examined in Southern Belize. This is similar to the findings of Roberts \& Polunin (1991) that suggested large areas of unprotected reef could produce as many eggs as small MPAs and that recruitment depends on larval dispersal pathways more than on the protected status of a site. The absence of early recruits in protected areas and their presence in heavily fished areas suggest that MPAs in Belize may not be adequately located or large enough to protect the sea cucumber resources. In fact, these MPAs were developed for other reasons. For instance, South Water Caye Marine Reserve was established in 1996 for its "outstanding universal value" as part of the Belize Barrier Reef System World Heritage Site (UNESCO World Heritage Center, 2017) and to protect valuable habitats for commercial and non-commercial species, including queen conch (Strombus gigas) and lobster (Panulirus argus), on which a number of coastal communities in Belize are dependent (Belize Fisheries Department, 2013). Nevertheless, the largest sea cucumbers were found inside MPAs when compared to other surveyed areas. This difference in size likely reflects the fact that large sea cucumbers (more visible and commercially valuable) are targeted by fishers, thereby decreasing their abundance outside protected boundaries. Therefore, while MPAs seem to protect adults (when no illegal fishing is taking place in these protected areas), these locations are apparently not promoting local recruitment.

Some tropical sea cucumbers have been demonstrated to have specific habitat preferences (Bruckner, Johnson, \& Field, 2003). In the present study, the largest individuals of $H$. mexicana were found associated with coral reef (in areas of sand and seagrass, or sand and coral rubble). The proximity of reef areas could play a role in providing food and habitat for sea cucumbers (Hasbún \& Lawrence, 2002; Conand, 2006; Toral-Granda, 2008), particularly when combined with seagrasses as 
is the case in the present study. Seagrass habitats were demonstrated to serve as settlement areas, and offer shelter and food to the newlysettled larvae and early juveniles of $H$. scabra (Mercier, Battaglene, \& Hamel, 2000). The presence of larger individuals in deeper waters, such as reef areas in this study, may be due to temperature gradients (Choe, 1963), as well as shelter (Sloan \& von Bodungen, 1980). Greater food availability in deep waters where organic content is the highest (Yingst, 1982) was also suggested for Stichopus japonicus (Choe, 1963) and Parastichopus parvimensis (Yingst, 1974). Although organic matter seems to be less abundant in reefs than in mangrove and seagrass meadows (Hemminga et al., 1994), corals are commonly found in close association with these two habitats and, depending on local hydrodynamics, seagrass-derived organic carbon may be exported to nearby environments (Unsworth et. al., 2008) including reef areas. Yet other studies suggest that habitat preference (Sloan \& von Bodungen, 1980) and distribution of most tropical holothuroids on reef flats is related to shelter from wave action (Bakus, 1973). It is also possible that the abundance of larger individuals in deeper water may simply be the result of fishing activities that deplete them from shallower areas, which are easier to access.

In comparison to previous studies, maximum sizes of $H$. mexicana found in Belize (47 $\mathrm{cm}$ ) were larger than in Panama (Guzman et al., 2003) and in Venezuela (Rodriguez-Milliet \& Pauls, 1998); but smaller than in Mexico (Fuente-Betancourt et al., 2001) and Florida (USA) (Engstrom, 1980). These differences in sizes could be related to the increasing fishing pressure promoting the disappearance of certain size classes. In Belize, it may suggest that the largest individuals are rare and have been harvested over the years, thereby skewing the population structure compared to earlier published work conducted before extensive fisheries started in the focal locations (e.g. in Mexico where the intensive fishing activity only began about 10 years ago). The largest individuals found here were also smaller than those reported by several fishers and exporters a few years ago, e.g. individuals of $91 \mathrm{~cm}$ in Half Moon Caye within the Lighthouse Atoll in Belize (Lincoln Cuevas, sea cucumber fisher, pers. comm., June 2012).

The sizes of $H$. mexicana found in all sites studied in Southern Belize also varied markedly, although the most common range was 20-24 $\mathrm{cm}$. Since size at sexual maturity was found to be around $10 \mathrm{~cm}$, fished populations are likely mainly composed of mature adult individuals. The present data highlighted a very low abundance of small individuals and juveniles in most sites, suggesting that the density of sexually mature sea cucumbers may no longer be high enough to ensure efficient fertilization during spawning periods. This type of Allee effect was described as a major impediment to the recovery of heavily fished sea cucumber populations, e.g. H. scabra on Warrior Reef, Australia (Skewes, Dennis, \& Burridge, 2000), Isostichopus fuscus in the Galapagos Marine Reserve, Ecuador (Toral-Granda \& Martinez, 2007), and H. nobilis on the Great Barrier Reef, Australia (Uthicke \& Benzie, 2000).

The minimum size at sexual maturity of $H$. mexicana found in Belize (10 cm in length) was smaller than that determined in Panama (13-15 cm) by Guzman et al., (2003). This size was also smaller than the $16 \mathrm{~cm}$ reported for H. atra in the Red Sea (Abdel-Razek et al., 2005), $20 \mathrm{~cm}$ for H. sanctori in Canary Islands (Spain) (Navarro, Garcia-Sanz, \& Tuya, 2012), $20 \mathrm{~cm}$ for H. grisea in Brazil (Leite-Castro et al., 2016), and $27 \mathrm{~cm}$ for Stichopus variegatus in New Caledonia (Conand, 1993b). In spite of its maximum size of $>50 \mathrm{~cm}$, comparable and sometimes larger than other previouslymentioned commercial tropical sea cucumbers, the small size at which sexual maturity was recorded in H. mexicana in Belize may reflect an adaptive strategy of the species, which is under heavy pressure from the fisheries. Maturation at younger and smaller sizes was proposed for other marine species as a result of high selective fishing pressure (as per Vainikka \& Hyvärinen, 2012; Pukk, Kuparinen, Järv, Gross, \& Vasemägi, 2013). 
The equal proportion of males and females in H. mexicana in Belize was similar to findings in the majority of tropical Holothuroidea species (e.g. Guzman et al., 2003; Foglietta, Camejo, Gallardo, \& Herrera, 2004; AbdelRazek et al., 2005; Muthiga, 2006; LeiteCastro et al., 2016). However, some uneven male:female sex ratios have been reported, such as 1.7:1 in H. fuscogilva in the Maldives (Reichenbach, 1999), 4:1 in $H$. nobilis in Micronesia (Amesbury et al., 1996) and 31:1 in $S$. chloronotus in La Reunion (Conand, Uthicke, \& Hoareau, 2002), all corresponding to heavily fished populations. As hypothesized previously by Birkeland \& Dayton (2005) and Fenberg \& Roy (2008), harvesting of large individuals can lead to depletion of one sex over the other (e.g. if a size difference exists between the sexes), thereby limiting the species reproductive potential. The $1: 1$ sex ratio found in the present study suggests that the maximum size of the heavily fished $H$. mexicana in Belize is similar in males and females and that both sexes were harvested equally. Moreover, the presence of hermaphroditic $H$. mexicana observed in Belize, also described in the sea cucumber I. fuscus in Mexico, may be linked to fishing pressure (Herrero-Pérezul, Reyes-Bonilla, \& Garcia-Dominguez, 1998). It has been hypothesized that, in places where population density of a species is so low, and conspecifics are rare, selection may enhance hermaphroditism and even self-fertilization. Inversely, if population density increases, the presence of hermaphrodites will decrease (Ghiselin, 1969).

Gametogenic stages and GI suggested synchronous gonad development in males and females in both years studied. Although a distinct indication of early gametogenesis (in February 2014 and January-February 2015) and clear spawning seasons were identified in this study (March-April 2014 and 2015 and in July-August 2015), some sea cucumbers with mature gonad stages were found throughout the year (between March and June 2014 and March and May 2015). This is similar to other studies of holothuroid reproduction, including
H. mexicana from other locations (Engstrom, 1980; Guzman et al., 2003), which suggests that not all individuals that reach gonad maturity are involved in spawning at the same time. Moreover, Leite-Castro et al. (2016) suggested that, although gametogenesis in $\mathrm{H}$. grisea may be monthly at the population level, it may be asynchronous among individuals in that population since only a portion of the individuals will spawn each month, as was also demonstrated in I. fuscus in Ecuador (Mercier et al., 2007) and H. atra in Northwestern Sri Lanka (Dissanayake \& Stefanssong, 2010).

Based on fluctuations in GI values and gametogenic stages, spawning was estimated to occur between March-April of both years. However, the spawning event in March-April 2015 was of smaller amplitude than the 2014 event and, despite clearly visible from the drop in GI and appearance of post-spawning stages, it was followed by a second weak spawning event in August-September 2015. Both spawning periods recorded in Belize in 2015 differ slightly from previous records for $H$. mexicana that placed the spawning period at the end of August in Florida, USA (Engstrom, 1980), in September and October in Curacao (van Veghel, 1993) and in May and July in Panama (Guzman et al., 2003), suggesting adaptation to local environmental conditions (see below). However, it is consistent with other high-latitude tropical sea cucumber species (Mercier \& Hamel, 2009) showing a seasonal reproductive period. The spawning period in both years was followed by months of gametogenic inactivity during which GI values were minimum and gonads were mostly in the recovery stage, as described in several other tropical and temperate sea cucumbers (Mercier \& Hamel, 2009).

The reproductive cycle of $H$. mexicana exhibited a seasonal pattern that was seemingly driven by environmental factors. Gametogenesis was initiated around February in both years (more defined in 2015), a period which corresponds to low rainfall, and increasing salinity, temperature and day length. Increases or decreases in temperature, day length and salinity were previously described as major factors 
influencing the initiation of gametogenesis in sea cucumbers (Mercier \& Hamel, 2009). In benthic marine invertebrates, spawning seasons often correspond to periods that favor recruitment success (Reitzel, Miner, \& McEdward, 2004). Spawning in H. mexicana clearly occurred during the most productive period of the year with maximum or highly fluctuating values of chlorophyll- $a$, increasing rainfall, increasing daylength and rapidly decreasing or increasing temperature. Rainfall in Southern Belize where $H$. mexicana is most abundant (Rogers, 2013) is the highest for the country with an annual average of about $4000 \mathrm{~mm}$ (National Meteorological Service of Belize, 2016). Increasing rain and runoff of terrigenous material coming from numerous rivers found along the coast could explain the increase of primary production (chlorophyll- $a$ ) and the beginning of the spawning period. This timing may well coincide with the presence of larvae of $H$. mexicana that feed on planktonic food, as also suggested by Leite-Castro et al. (2016) for $H$. grisea and by Chao et al. (1995) for Actinopyga echinites, $H$. leucospilota and $H$. difficilis in southern Taiwan. Such a correlation between primary production and sea cucumber spawning was also observed in the temperate species Psolus fabricii (Hamel et al., 1993) and Cucumaria frondosa (Hamel \& Mercier, 1995) and the tropical species H. grisea (Leite-Castro et al., 2016). Guzman et al. (2003) also suggested a relationship between GI values and temperature in H. mexicana in Panama. Here, both annual spawning periods coincided with the highest high tides and highest low tides, similar to the findings of Leite-Castro et al. (2016), suggesting that spawning dates could be determined by the tidal cycle and the related water level. High tides acting as spawning cues were also reported for A. echinites (Desurmont, 1996) and Bohadschia similis (Desurmont, 2004), and believed to facilitate the dispersion of the propagules with currents. Finally, the period characterized by the lowest GI values and a dominance of gonads in recovery stages in the present study was between August and January, corresponding to the period of shortest daylengths, coldest temperatures, stable salinity and minimal rainfall.

The results presented here call for additional studies that seek to understand the adaptive strategies in $H$. mexicana and the role that adults play in coral reef communities. Investigations of nursery habitats are also needed to fully understand the life cycle and early life-history strategies of $H$. mexicana. While efforts are being deployed to learn more about the species, it is critical to protect its habitat and restrict fishing around the spawning months because the resource has already been heavily exploited.

\section{ACKNOWLEDGMENTS}

Thanks to the Oak Foundation and the University of Belize Environmental Research Institute for funding this study; CINVESTAV's M. Olvera, G. Martinez, I. Sanchez-Tapia; the Belize Fisheries Department and fishermen of Independence Village \& Punta Gorda; UB-ERI student volunteer A. Barrias and team for their invaluable support with specimen collection. Sincere thanks as well to two anonymous reviewers for their comments on an earlier draft of this work. Finally, thanks to C. Cumberbatch of the National Meteorological Service of Belize; P. Haylock, J. Trejo and H. Sanchez at Central Pathology Laboratory in the Ministry of Health; R. Manzanero, G. Mai and A. Vasquez from the Belize Agriculture Health Authority; and H. Bahena-Basave for his support with microscopy.

\section{RESUMEN}

Estructura de la población y ciclo reproductivo del pepino de mar comercial Holothuria mexicana (Echinodermata: Holothuroidea) en Belice. La población y la biología reproductiva de pepino de mar comercial Holothuria mexicana (Ludwig, 1875) fue estudiado en el sur de Belice (Mar Caribe), incluyendo la proporción de sexo, talla de madurez sexual y el ciclo reproductivo, así como la estructura de tamaño entre hábitats situados dentro y fuera de áreas marinas protegidas. Los individuos dentro de las áreas marinas protegidas fueron siempre mayores que los individuos encontrados fuera de estos límites. La 
proporcion de machos a hembras fue de 1.1:1.0, con una distribución de tamaño unimodal compuesta principalmente de individuos sexualmente maduros (87\%). La talla de madurez sexual fue $\sim 10 \mathrm{~cm}$ basada en medidas de individuos con gametos maduros durante el período del pico de maduracion de gametos. Los juveniles y adultos pequeños de medidas $\leq 15 \mathrm{~cm}(13.1 \%)$, fueron recogidos exclusivamente en zonas fangosas y arenosas en pastos marinos asociados con los manglares. Los adultos mayores se encontraban comúnmente sobre substratos duros tanto en pastos marinos asociados como en los arrecifes de coral. Basada en la histología y gónada de índices, el primer signo de la gametogénesis temprana fue detectado en Agosto en ambos sexos. Los gametos en desarrollo y maduros se encontraron durante los meses fríos entre Noviembre y Febrero. Las disminuciones en el índice gonadal en ambos años sugieren desove anual, el cual comenzó en Marzo y Abril de 2014 (único gran evento) y en Marzo-Abril y Julio-Agosto de 2015 (dos pequeños eventos) tanto para ambos sexos durante temperaturas más cálidas, escasas precipitaciones y altas concentraciones de clorofila-a. Con estos datos esperamos orientar la gestión y la protección de las poblaciones naturales de $H$. mexicana, que ya están sufriendo los efectos de la sobrepesca en Belice y países vecinos.

Palabras clave: equinodermo; holothuroidea; área marina protegida; época reproductiva; madurez sexual; estructura de tamaño.

\section{REFERENCES}

Abdel-Razek, F., Abdel-Rahman, S., El Shimy, N. A., \& Omar, H. (2005). Reproductive biology of the tropical sea cucumber Holothria atra in the Red Sea coast of Egypt. Egyptian Journal of Aquatic Research, 31(2), 383-402.

Alvarado, J. J., Solis-Marin, F. A., \& Ahearn, C. (2008). Equinoderms (Echinodermata) of the Central American Caribbean. Revista de Biologia Tropical, 56(Suplement 3), 37-55.

Amesbury, S. S., Callaghan, P., Hopper, D., Kerr, A., Martinez, P., \& Richmond, R. H. (1996). Management of beche-de-mer resources in Micronesia. In R. H. Richmond (Ed.), Suggestions for the Management of Sea Cucumber Resources in Micronesia (pp. 32-41). Mangilao, Guam: University of Guam Marine Laboratory.

Anderson, S. C., Flemming, J. M., Watson, R., \& Lotze, H. K. (2011). Serial exploitation of global sea cucumber fisheries. Fish and Fisheries, 12(3), 317-339.

Bakus, G. J. (1973). The biology and ecology of tropical holothurians. In O. A. Jones, \& R. Endean (Eds.), Biology and geology of coral reefs (Vol. 11, Biology I, pp. 325-367). New York: Academic Press.
Balogh, R., Wolfe, K., \& Byrne, M. (2018). Gonad development and spawning of the vulnerable commercial sea cucumber, Stichopus herrmanni, in the southern Great Barrier Reef. Journal of the Marine Biological Association of the United Kingdom (in press).

Belize Fisheries Department. (2013). South Water Caye. Retrieved from http://www.fisheries.gov.bz/ south-water-caye

Birkeland, C., \& Dayton, P. K. (2005). The importance in fishery management of leaving the big ones. Trends in Ecology and Evolution, 20, 356-358.

Bolaños, N., Bourg, A., Gómez, J., \& Alvarado, J. J. (2005). Equinoderm diversity and abundance in the lagoon reefs in the Cahuita National Park, Caribbean Costa Rica. Revista de Biologia Tropical, 53, 285-290.

Bruckner, A. (Ed.). (2006). Proceedings of the CITES workshop on the conservation of sea cucumbers in the families Holothuriidae and Stichopodidae. Kuala Lampur, Malaysia. U.S. Department of Commerce, National Oceanic and Atmospheric Administration.

Bruckner, A. W., Johnson, K. A., \& Field, J. D. (2003). Conservation strategies for sea cucumbers: Can a CITES Appendix II listing promote sustainable international trade? SPC Beche-de-Mer Information Bulletin, 18, 24-33.

Cameron, J. L., \& Fankboner, P. V. (1986). Reproductive biology of the commercial sea cucumber Parastichopus californicus (Echinodermata: Holothuroidea). I. Reproductive periodicity and spawning behavior. Canadian Journal of Zoology, 64, 168-175.

Chao, S., Chen, C. P., \& Alexander, P. S. (1994). Reproduction and growth of Holothuria atra (Echinodermata: Holothuroides) at two contrasting sites in southern Taiwan. Marine Biology, 119, 565-570.

Chao, S. M., Chen, C. P., \& Alexander, P. (1995). Reproductive cycles of tropical sea cucumbers (Echinodermata: Holothuroidea) in southern Taiwan. Marine Biology, 122(2), 289-295.

Choe, S. (1963). Biology of the Japanese common sea cucumber Stichopus japonicus Selenka (Doctoral dissertation). Pusan National University, South Korea.

Conand, C. (1981). Sexual cycle of three commercially important Holothurian species (Echinodermata) from the lagoon of New Caledonia. Bulletin of Marine Science, 31(3), 523-543.

Conand, C. (1982). Reproductive cycle and biometric relations in a population of Actinopyga echinites (Echinodermata: Holothuroidea) from the lagoon of New Caledonia, western tropical pacific. In J. M. Lawrence (Ed.), International Echinoderm Conference (pp. 437-442). Tampa Bay, Florida, USA: Balkema, Rotterdam. 
Conand, C. (1993a). Reproductive biology of the holothurians from the major communities of the New Caledonian Lagoon. Marine Biology, 116, 439-450.

Conand, C. (1993b). Ecology and reproductive biology of Stichopus variegatus an Indo-Pacific coral reef sea cucumber (Echinodermata: Holothuroidea). Bulletin of Marine Science, 52(3), 970-981.

Conand, C. (2006). Sea cucumber biology, taxonomy, distribution: conversation Status. In A. W. Bruckner (Ed.), Proceeding of the technical workshop on the conservation of sea cucumbers in the families Holothuridae and Stichopodidae (pp. 35-50). Kuala Lumpur, Malaysia: NOAA Technical Memorandum.

Conand, C., Uthicke, S., \& Hoareau, T. (2002). Sexual and asexual reproduction of the holothurian Stichopus chloronotus (Echinodermata): a comparison between La Reunion (Indian Ocean) and east Australia (Pacific Ocean). Invertebrate Reproduction \& Development, 41(1-3), 235-242.

Costelloe, J. (1985). The annual reproductive cycle of the holothurian Aslia lefevrei (Dendrochirota: Echinodermata). Marine Biology, 88(2), 155-165.

Desurmont, A. (1996). Spawning and asexual reproduction of tropical holothurians. SPC Beche-de-mer Information Bulletin, 8, 41.

Desurmont, A. (2004). Natural spawning observations Bohadschia similis. SPC Beche-de-mer Information Bulletin, 20, 37.

Dissanayake, D. C. T., \& Stefanssong, G. (2010). Reproductive biology of the commercial sea cucumber Holothuria atra (Holothuroidea: Aspidochirotida) in the northwestern coastal waters of Sri Lanka. Invertebrate Reproduction Development, 54, 65-76.

Drumm, D. J., \& Loneragan, N. R. (2004). Reproductive biology of Holothuria leucospilota in the Cook Islands and the implications of traditional fishing of gonads on the population. New Zealand Journal of Marine and Freshwater Research, 39(1), 141-156.

Engstrom, N. (1980). Reproductive cycles of Holothuria (Halodeima) floridana, H. (H.) mexicana and their hybrids (Echinodermata: Holothuroidea) in southern Florida, USA. International Journal Invertebrate Reproduction, 2, 237-244.

Fenberg, P. B., \& Roy, K. (2008). Ecological and evolutionary consequences of size-selective harvesting: How much do we know? Molecular Ecology, 17, 209-220.

Foglietta, L. M., Camejo, M. I., Gallardo, L., \& Herrera, F. C. (2004). A maturity index for holothurians exhibiting asynchronous development of gonad tubules. Journal of Experimental Marine Biology and Ecology, 303, 19-30.
Foley, J., Alvarez, M., Moore, R., Requena, E., \& Warns, D. (2015). Ridge to reef water quality. Port Honduras Marine Reserve, Monkey River, Rio Grande. Marine and freshwater water quality monitoring annual report. Punta Gorda Town: Toledo Institute for Development and Environment.

Fuente-Betancourt, M. G., Jesús-Navarrete, A., SosaCordero, E., \& Herrero-Perezrul, M. D. (2001). Assessment of the sea cucumber (Echinodermata : Holothuroidea) as potential fishery resource in Banco Chincorro, Quintana Roo, Mexico. Bulletin of Marine Science, 68(1), 59-67.

Galigher, A. E., \& Kozloff, E. N. (1971). Essentials of Practical Microtechniques $\left(2^{\circ}\right.$ ed). Philadelphia: Lea and Febiger.

Ghiselin, M. T. (1969). The evolution of hermaphroditism among animals. Quarterly Review of Biology, 44, 189-208.

Global Companies. (2015). Haitian sea products. Retrieved from http://www.companiess.com/haitian sea products_info $1332128 . \mathrm{html}$

Guzman, H. M., \& Guevara, C. A. (2002). Population structure, distribution and abundance of three commercial species of sea cucumber (Echinodermata) in Panama. Caribbean Journal of Science, 38(3-4), 230-238.

Guzman, H. M., Guevara, C. A., \& Hernandez, I. C. (2003). Reproductive cycle of two commercial species of sea cucumber (Echinodermata: Holothuroidea) from Caribbean Panama. Marine Biology, 142(2), 271-279.

Hamel, J.-F, Himmelman, J. H., \& Dufresne, L. (1993). Gametogenesis and spawning of the sea cucumber Psolus fabricii (Duben and Koren). Biological Bulletin, 184, 125-143.

Hamel, J.-F., \& Mercier, A. (1995). Spawning of the sea cucumber Cucumaria frondosa in the St Lawrence Estuary, eastern Canada. SPC Beche-de-Mer Information Bulletin, 7, 12-18.

Hamel, J.-F. \& Mercier, A. (1996). Evidence of chemical communication during the gametogenesis of holothuroids. Ecology, 77, 1600-1616.

Hasbún, C. R., \& Lawrence, A. J. (2002). An annotated description of shallow water Holothurians (Echinodermata: Holothuroidea) from Cayos Cochinos, Honduras. Revista de Biología Tropical, 50(2), 669-678.

Hemminga, M. A., Slim, F. J., Kazungu, J., Gansen, G. M., Nieywenhuize, J., \& Kruyt, N. M. (1994). Carbon outwelling from a mangrove forest with adjacent seagrass beds and coral reefs (Gazi Bay, Kenya). Marine Ecology Progress Series, 106, 291-301. 
Hendler, G., Miller, J. E., Pawson, D., \& Kier, P. M. (1995). Sea stars, sea urchins and allies: echinoderms of Florida and the Caribbean. Washington: Smithsonian Institution Press.

Hendler, G., \& Pawson, D. L. (2000). Echinoderms of the rhomboidal cays, Belize: biodiversity, distribution and ecology. Atoll Research Bulletin, 479, 273-299.

Herrero-Pérezrul, M. D., Reyes-Bonilla, H., \& GarcíaDomínguez, F. (1998). Casual hermaphroditism in gonochoric Isostichopus fuscus (Ludwig, 1875) (Echinodermata: Holothuroidea) of the Southern Gulf of California, Mexico. Bulletin of Marine Science, 3(63), 611-615.

Herrero-Perezrul, M. D., Reyes Bonilla, H., GarciaDominguez, F., \& Cintra-Buenrostro, C. E. (1999). Reproduction and growth of Isostichopus fuscus (Echinodermata: Holothuroidea) in the southern Gulf of California, Mexico. Marine Biology, 135, 521-532.

Hopper, D. R., Hunter, C. L., \& Richmond, R. H. (1998) Sexual reproduction of the tropical sea cucumber, Actinopyga mauritana (Echinodermata: Holothuroidea), in Guam. Bulletin of Marine Science, 63(1), 1-9.

IBM Corp. (2012). IBM SPSS Statistics for Windows (Version 21.0). Armonk, NY: IBM Corp.

Jamaica Observer. (2015). Gov't bans sea cucumber fishing ahead of J\$30-m study. Retrieved from http://www. jamaicaobserver.com/news/Gov-t-bans-sea-cucumber-fishing-ahead-of-J-30-m-study

Kong, A. (2016). The sea cucumber fishery in Jamaica. Retrieved from http://www.infopesca.org/sites/ default/files/complemento/actividadesregionales/ adjuntos/1215/5.5-Pepinodemar-Jamaica.pdf

Krishnaswamy, S., \& Krishnan, S. (1967). A report on the reproductive cycle of the holothurian Holothuria scabra Jaeger. Current Science, 36, 155-156.

Leite-Castro, L. V., de Souza Junior, J., Brito SalmitoVanderley, S. C., Ferreira Nunes, J., Hamel, J.-F., \& Mercier, A. (2016). Reproductive biology of the sea cucumber Holothuria grisea in Brazil: importance of social and environmental factors in breeding coordination. Marine Biology, 163(67), 1-13.

Masters, J. (2014). CRFM Statistics and Information Report - 2012. CRFM Secretariat Belize and St. Vincent and the Grenadines. Retrieved from http://www. crfm.net/images/CRFM Statistics and Information Report_2012_final_draft_27_Jan_2015_1_1.pdf

McEuen, F. S. (1988). Spawning behaviors of northeast Pacific sea cucumbers (Holothuroidea: Echinodermata). Marine Biology, 98, 565-585.

Mercier, A., Battaglene, S., \& Hamel, J.-F. (2000). Periodic movement, recruitment and size-related distribution of the sea cucumber Holothuria scabra in Solomon Islands. Hydrobiologia, 440, 81-100.

Mercier, A., \& Hamel, J.-F. (2009). Endogenous and exogenous control of gametogenesis and spawning in echinoderms. Advances on Marine Biology, 55(09), 1-302.

Mercier, A., Ycaza, R. H., \& Hamel, J.-F. (2007). Longterm study of gamete release in a broadcast-spawning holothurian: predictable lunar and diel periodicities. Marine Ecology Progress Series, 329, 179-189.

Mobile Geographics. (2016). Tide table: Belize City, Beli$z e$. Retrieved from http://tides.mobilegeographics. com/calendar/year/493.html?y=2015\&m=1\&d=1

Mosher, C. (1982). Spawning behaviour of the aspidochirote holothurian Holothuria mexicana Ludwig. In J. M. Lawrence (Ed.), Proceedings of the International Echinoderm Conference (pp. 467-468). Tampa Bay: A.A. Balkema, Rotterdam.

Muthiga, N. (2006). The reproductive biology of a new species of sea cucumber, Holothuria (Mertensiothuria) arenacava in a Kenyan marine protected area: the possible role of light and temperature on gametogenesis and spawning. Marine Biology, 149(3), 585-593.

NASA. (2015). MODIS Chlorophyll-a Concentration. Retrieved from http://oceancolor.gsfc.nasa.gov/cgi/ browse.pl?sen=am

National Meteorological Service of Belize. (2016). Climate Summary. Retrieved from http://www.hydromet.gov. bz/climate-summary

National Meteorological Service of Belize. (2017). Climate Summary. Retrieved from http://www.hydromet.gov. bz/climate-summary

Navarro, P. G., García-Sanz, S., \& Tuya, F. (2012). Reproductive biology of the sea cucumber Holothuria sanctori (Echinodermata: Holothuroidea). Scientia Marina, 76(4), 741-752.

Pawson, D. L. (1976). Shallow-water sea cucumbers (Echinodermata: Holothuroidea) from Carrie Bow Cay, Belize. Proceedings of the Biological Society of Washington, 89(31), 369-382.

Perez, A., \& Garcia, O. D. (2012). Socioeconomic assessment of the sea cucumber fishery in Belize. Belmopan, Belize: University of Belize Environmental Research Institute.

Pukk, L., Kuparinen, A., Järv, L., Gross, R., \& Vasemägi, A. (2013). Genetic and life-history changes associated with fisheries-induced population collapse. Evolutionary Applications, 6, 749-760.

Ramdeen, R., Belhabib, D., Harper, S., \& Zeller, D. (2012). Reconstruction of total marine fisheries catches for 
Haiti and Navassa Island (1950-2010). In S. Harper, K. Zylich, L. Boonazaier, F. Le Manach, D. Pauly, \& D. Zellet (Eds.), Fisheries Catch Reconstructions: Islands, Part II (pp. 37-45). Vancouver: University of British Columbia.

Ramofafia, C., Battaglene, S. C., Bell, J. D., \& Byrne, M. (2000). Reproductive biology of the commercial sea cucumber Holothuria fuscogilva in the Solomon Islands. Marine Biology, 136, 1045-1056.

Rasolofonirina, R., Vaitilingon, D., Eeckhaut, I., \& Jangoux, M. (2007). Reproductive cycle of edible echinoderms from the Southwestern Indian Ocean II: The Sandfish Holothuria scabra (Jaeger, 1833). Western Indian Ocean Journal of Marine Science, 4(1), 61-75.

Reichenbach, N. (1999). Ecology and fishery biology of Holothuria fuscogilva (Echinodermata: Holothuroidea) in the Maldives, Indian Ocean. Bulletin of Marine Science, 64(1), 103-113.

Reitzel, A. M., Miner, B. G., \& McEdward, L. R. (2004). Relationships between spawning date and larval development time for benthic marine invertebrates: a modeling approach. Marine Ecology Progress Series, 280, 13-23.

Roberts, C. M., \& Polunin, N. V. C. (1991). Are marine reserves effective in management of reef fisheries? Reviews in Fish Biology and Fisheries, 1(1), 65-91.

Rodriguez-Milliet, E., \& Pauls, S. M. (1998). Sea cucumber fisheries in Venezuela. In R. Mooi (Ed.), Proceedings of the 9th International Echinoderm Conference (pp. 513-516). San Fransisco, California, USA: Balkema, Rotterdam.

Rogers, A. (2013). Density, abundance and distribution of sea cucumbers in Belize. Proceedings of the Gulf and Caribbean Fisheries Initiative (pp. 483-486). Chorpus Christi, Texas, USA: Gulf and Caribbean Fisheries Institute.

Rogers, A., Hamel, J.-F., Baker, S., \& Mercier, A. (2018). The 2009-2016 Belize sea cucumber fishery: Resource use patterns, management strategies and socioeconomic impacts. Regional Studies in Marine Science, 22, 9-20.

Rogers, A., Hamel, J.-F., \& Mercier, A. (2017). From lifesustaining to life-threatening: The case of the sea cucumber fishery in Nicaragua. SPC Beche-de-Mer Information. Bulletin, 37, 48-50.

SAGARPA (2015). Closed seasons for marine and freshwater species. Retrieved from http://www. conapesca.gob.mx/work/sites/cona/resources/ PDFContent/14619/presentaioc.pdf

Shiell, G. R., \& Uthicke, S. (2006). Reproduction of the commercial sea cucumber Holothuria whitmaei [Holothuroidea: Aspidochirotida] in the Indian and
Pacific Ocean regions of Australia. Marine Biology, 148(5), 973-986.

Skewes, T., Dennis, D., \& Burridge, C. (2000). Survey of Holothuria scabra (sandfish) on Warrior Reef, Torres Strait. Report to Queensland Fisheries Management Authority, Queensland, Australia. Queensland, Australia: CSIRO Division of Marine Research.

Sloan N. A., \& von Bodungen, B. (1980). Distribution and feeding of the sea cucumber Isostichopus badionotus in relation to shelter and sediment criteria of the Bermuda platform. Marine Ecology Progress Series, 2, 257-264.

Smiley, S., McEuen, F., Chaffee, C., \& Krishan, S. (1991). Echinodermata: Holothuroidea. In A. Giese, J. Pearse, \& V. Pearse (Eds.), Reproduction of Marine Invertebrates: Echinodermata and Lophophorate (pp. 663-750). Pacific Grove, California: The Boxwood Press.

Tagliafico, A., Rangel, M. S., \& Rago, N. (2011). Density and Distribution of two species of holoturoids in Cubagua Island, Venezuela. Revista de Biología Tropical, 59(2), 843-852.

Time and Date AS. (2015). Belize City, Belize - Sunrise, Sunset and Daylength. Retrieved from https://www.timeanddate.com/sun/belize/ belize-city?month=1\&year $=2014$

Toral-Granda, V. (2008). Population status, fisheries and trade of sea cucumbers in Latin America and the Caribbean. In V. Toral-Granda, A. Lovatelli, \& M. Vasconcellos (Eds.), Sea Cucumbers: A Global Review of Fisheries and Trade (pp. 211-229). FAO Fisheries and Aquaculture Technical Paper No. 516. Rome: FAO.

Toral-Granda, M. V., Alvarado, J. J., Benavides, M., Ortiz, P., Mercier, A., \& Hamel, J.-F. (2013). Holothuria mexicana. Retrieved from http://www.iucnredlist.org/ details/180492/0

Toral-Granda, M. V., \& Martínez, P. C. (2007). Reproductive biology and population structure of the sea cucumber Isostichopus fuscus (Ludwig, 1875) (holothuroidea) in Caamaño, Galápagos Islands, Ecuador. Marine Biology, 151, 2091-2098.

UNESCO World Heritage Center. (2017). Belize barrier reef reserve system. Retrieved from http://whc. unesco.org/en/list/764

Unsworth, R. K. F., De Leon, P. S., Garrard, S., Jompa, J., Smith, D. J., \& Bell, J. J. (2008). High connectivity of Indo-Pacific seagrass fish assemblages with mangrove and coral reef habitats. Marine Ecology Progress Series, 353, 213-224.

Uthicke, S., \& Benzie, J. A. H. (2000). Effect of bechede-mer fishing on densities and size structure of Holothuria nobilis (Echinodermata: Holothuroidea) 
populations on the Great Barrier Reef. Coral Reefs, 19, 271-276.

Vainikka, A., \& Hyvärinen, P. (2012). Ecologically and evolutionarily sustainable fishing of the pikeperch Sander lucioperca: Lake Oulujärvi as an example. Fisheries Research, 113, 8-20.

van Veghel, M. L. J. (1993). Multiple species spawning on Curacao reefs. Bulletin of Marine Science, 52, 1017-1021.
Yingst, J. (1974). The utilization of organic detritus and associated microorganisms by Parastichopus parvimensis, a benthic deposit-feeding holothurian (Doctoral dissertation). University of South California, USA. Retrieved from https://elibrary.ru/item. asp?id $=7139187$

Yingst, J. Y. (1982). Factors influencing rates of sediment ingestion by Parastichopus parvimensis (Clark), and epibenthic deposit-feeding holothurian. Estuarine, Coastal and Shelf Science, 14, 119-134. 